\title{
Assessments of the effects of permanent internal migration in the Russian literature at the late 19th and early 20th centuries
}

\author{
Valentina M. Moiseenko' \\ 1 Independent researcher, Moscow, 119991, Russia
}

Received 10 January 2019 • Accepted 24 April 2019 • Published 30 June 2019

Citation: Moiseenko VM (2019) Assessments of the effects of permanent internal migration in the Russian literature at the late 19th and early 20th centuries. Population and Economics 3(2): 10-21. https://doi.org/10.3897/ popecon.3.e37973

\begin{abstract}
In the context of the agrarian crisis in Russia (USSR) in the second half of the 19th and the first third of the 20th century, much attention in the socio-political literature was paid to the migration of peasants to the extensive undeveloped areas, mainly to the east of the Ural mountains. The changing characteristics of migration and migration policies during this period have resulted in a variety of methods for assessing the effects of migration. The experience of the second half of the 19th and the first third of the 20th century is interesting not only in the dynamics of assessment of the effects, but also in the logical conclusion of the study of this problem. It is known that even today the effects of migration remain a complex and largely unsolved research task.
\end{abstract}

\section{Keywords}

migration of peasants; assessment of efficiency of resettlement; colonization; welfare of migrants; capital and labour costs for migration

JEL Codes: J0, J1, N5

\section{Estimation of the effects of migration in the late 19th - early 20th centuries}

In the framework of the first stage (1880s - 1890s) leading scientists of Russia set the task of assessing the scale of migration of peasants supported by the state. In 1875 V.I. Chaslavskiy was one of the first to oppose the effects of permanent migration of peasants to the negative consequences of seasonal movements of peasants for employment and defined migration 
supported by the state as a factor of "progress in the development of people's forces and wealth" (Chaslavskiy 1875: 210). A.I. Vasilchikov, defending the need for the state to organize and support migration of peasants, claimed: "No land situation, no agrarian and social system can be considered perfect, complete and lasting unless it is complemented by a proper system of colonization." A.I. Vasilchikov saw social results of relocation in the "equation of land plots" and "reasonable settlement of the population" (1881: 321, 387).

The first surveys of peasant farms in the 1880s in the Vyatka and Ryazan provinces (Romanov 1880; Grigoriev 1885) showed a significant scale of permanent migration of peasants and their positive effects for migrants. In the Altai region - the center of attraction of migrants flows - growth of welfare of rural migrants in comparison with the welfare of peasants in places of departure and Siberian old-timers was noted (Chudnovsky 1884). It should be noted that these findings were based on the scant data on the situation of migrant farms, but with the further development of rural migration, a need for information covering a large set of farms emerged.

At the first stage, assessment of the effects of migration of peasants from the European to Asian Russia was mainly reflecting the perspective of the interests of the departure areas. In 1880s-1890s the scale of rural migration was critically assessed as a palliative of the solution of the agrarian issue. It was believed that in order to improve the situation of the peasants in the "internal provinces" it was necessary to move out about half of the inhabitants from the Chernozem zone. Taking into account the irreality of such a task, attention was drawn to the negative political consequences of the growing land scarcity of peasants in European Russia (Gurvich 1888: 103-104). In the early 1890s, annual rates of out-migration (about 90,000 persons) were also estimated to be disproportionately low in relation to the annual population growth in 50 provinces of European Russia (about 1 million persons in 1885). At the same time, material support of the state to immigrants was considered one of the most "productive expenditures of the treasury" (Isayev 1891: 135-136, 142). Opponents of resettlement saw its negative consequences in the areas of departure in rising wages of workers and decrease in profitability of medium and large land holdings.

However, already in the early 1890 s attention of researchers increasingly began to be paid to the interests of destination areas. Thus, the in-flow of peasants was considered a necessary condition for the development of Siberia. The resettlement policy of the state was supposed to result in "wealthy producers" "instead of the poor proletarians" (Yadrintsev 1892: 211-212).

Speaking of the results of the first stage of the study of the effects of migration of peasants, increased participation of the state in the organization of resettlement (laws of 1881 and 1889), the increase in their scope, especially in the period of activity of the Committee of the Siberian Railway (1894-1903), development of migration statistics (1894) and creation of the Migration Directorate in the Ministry of Internal Affairs of Russia (1897) should be noted. Assessment of the effects of migration focused mainly on the changes in the situation of migrants' households in the places of destination compared to the places of departure, as well as the scale of migration. At the same time, the view on the importance of inflow of rural migrants for the development of destination areas was substantiated.

In the second stage (1900-1914), the effects of migration were assessed in the context of the Stolypin agrarian reform. The increase in the scale of migration corresponded to the public mood, in particular, the position of provincial county council committees (Nuzhdy sel'skogo... 1902: 14-120). In the early 20th century A.A. Kaufman, who made a significant contribution to the study of migration in Russia and assessed the socio-economic significance of this process differently at various stages, proposed in the early 20 th century to con- 
sider resettlement "solely as a fact of real life". According to A.A. Kaufman, the migration policy was supposed, on the one hand, to facilitate resettlement for those who wished to relocate, and, on the other hand, to reduce the number of people wishing to relocate. The then crisis of the peasant economy supposed that the State concerns for migration should not draw it attention away from "the indigenous..., more complicated concerns for the improvement of peasant welfare and peasant culture" (Kaufman, 1905: 349).

In the early 20th century, the growth of the scale of rural migration and increased related expenditures of the state called for in-depth assessment of the effects of migration. Publications of the Migration Directorate mainly demonstrated the effects of migration in places of destination. Among these, most significant were demographic consequences. The number of family migrants and khodoki $i^{1}$ from European Russia to the east of the Urals in 1885-1913 was 5159 thousand people, return (family) migrants amounted to 517 thousand persons (14\%). The peak of resettlements (744-682 thousand persons) occurred in 19081909. (Kaufman no date (a): 2-3). Annual government expenditure on migrants increased from 3-4 million rubles in the period of activity of the Committee of the Siberian Railway to 30 million rubles in 1914 (excluding the expenses of the migrants themselves) (Kaufman no date (b): 538). The welfare of migrants in the places of destination was generally higher than in places of departure. The total quitrent in Siberia grew from 6 million to 13 million rubles between 1906 and 1913. The area under crop in Asian Russia was increasing annually by almost 1 million dessiatinas (2.7 million acres) between 1908 and 1914. Exports of plant oil in 1913 reached 5 million poods (84 million $\mathrm{kg}$ ) per year worth 75 million rubles. In 1913, the Siberian railway received 13.5 million rubles of net income. Indirect tax collection increased under the influence of population needs (Zhurnaly Komissii... 1917: 137-138).

In 1897 the population of 12 provinces of Siberia was 8,184.4 thousand persons, in 1917 it was estimated at 14,440.1 thousand persons. The annual increase of the Siberian population $(3.8 \%)$ was almost three times higher than that of European Russia (1.3\%). The urban population of Siberia grew one and a half times faster than the urban population of European Russia (6\% and 4\% respectively) (Oganovsky 1921: 35-36). Despite the decolonization trend in Siberia in 1922-1924, the All-Union population census of 1926 confirmed the great role of pre-war migration inflow to the population growth of the Asian part of the USSR. Net migration of the population, i.e. the difference between the number of persons from other USSR territories who arrived in the Asian part and the number of natives of the Asian part registered in other regions, was estimated in the amount of 1,125.4 thousand persons in the RSFSR, including 638.7 thousand persons in the Kazakh ASSR, 68.1 thousand persons in the Kyrgyz ASSR, 1986.5 thousand persons in the Siberian region and 337.5 thousand persons in the Far East. Positive population growth due to migration amounted to 196.3 thousand persons in the Uzbek SSR and 62.8 thousand people in the Turkmen SSR (Vsesojuznaja perepis... 1931: 174-175).

At the same time, the increase in migration flows revealed the contradictory results of this process. The assessment of the scale of migration continued to be pessimistic. About 1.2 million persons resettled from the 50 provinces of European Russia in 1885-1901, while natural growth of the rural population was about 20 million people (Manuilov 1905: 65)]. The share of migrants in the growth of the rural population of 50 provinces in 1895-1900

${ }^{1}$ Khodoki - here: peasants who were sent by community to the new territories as pioneers to evaluate conditions of life and state of land in the supposed place of destination and prepare the further migration of their families and fellow-villages. 
was $10.7 \%$, in $1900-1904-4.2 \%$, in $1905-1909-24.5 \%$. The resulting conclusion was that it was impossible to eliminate the agrarian crisis by means of migration (Zapiska Predsedatelja... 1910: 83; Oganovsky 1914: 62).

Discussion of the results of the survey of the social and economic situation of migrants conducted in 1911-1912 and covering 447 settlements with 32 thousand households, revealed their significant differences in different areas (Kuznetsov no date: 69-83; Kaufman 1915: 299-320; and others] The need to achieve a sustainable social and economic situation of migrants in areas of destination was recognized as an urgent task. Since the beginning of the 20th century, there were more and more contradictions between migrants and Siberian residents, between migrants and indigenous inhabitants of the Steppe Territory and Turkestan, between provinces of departure and destination. Coordination of interests of the provinces of European Russia with the interests of the provinces of Asian Russia was considered a more difficult task than regulation of relations of the countries of emigration and immigration (Berkenheim 1902: 3). Intra-Russia rural migration failed to prevent mass emigration from Russia, as previously supposed (Vasilchikov 1881; and others).

Despite the contradictory effects of migration, the concept of future development of Asian Russia took into account its positive results. In contrast to the migration policy in previous years, described as a self-pressing state task, in 1910 the idea of active colonization of Asian Russia with the support of the state was put forward (Simonov 1917: 16). The focus of the migration policy of the state was shifted from the number of migrants to providing migrants with necessary facilities. To this end, it was intended to overcome the difference of views on the importance of migration.

The concept of colonization involved the development of the productive forces of Asian Russia through implementation of a complex of agricultural, economic and technical measures for land reclamation, construction of a road network, overcoming the crisis of extensive forms of agriculture, etc. (Oganovsky 1914: 308). Taking into account the adopted Western European vector of development of Russia, the problem of agrarian overpopulation of European Russia was supposed to be solved with the help of industrialization of the country, albeit slow. But since the industrial (urban) sector of the economy could absorb natural population growth only partially, the relocation of excess population to Asian Russia was considered as "the second largest movement factor by magnitude of the excessive rural population" (Oganovsky 1914: 61, 247, 306). At the same time, measures to protect the land interests of old residents and indigenous people in Asian Russia had to be taken.

As we see, the second stage demonstrated a significant step towards overcoming the narrow approach in the evaluation of the effects of migration, which took into account mainly the scale of migration from European to Asian Russia. The expanded range of indicators of migration effects focused primarily on the socio-economic development of destination areas. However, in the face of increasing expenditures on migration, the cost-effectiveness of migration remained underdeveloped. There was an attempt to fill this gap within the third stage in the late 1920 s.

\section{Estimation of the efficiency of migration in the 1920s}

After the period of the "military communism", the introduction of laws regulating internal and external population movements became a prerequisite for the "new economic policy". 
Under the pressure of the spontaneous population movements in the RSFSR, the planned resettlement of peasants in multi-land virgin areas was started in 1924.

Despite the obvious difficulties, interest in resettlement of peasants in the first years of Soviet power remained great, that is confirmed by the detailed elaboration of colonization policy in the North of European Russia at the late 1910s and early 1920s. (Chirkin 1917: 1-14; and others) Given the long history of rural migration in Russia and the agrarian overpopulation persisting in the 1920s and, as it was believed, the new opportunities of the planned economy, it was offered to consider resettlement as the basis of new land organization in the near future (Voshchinin 1921: 139). In the mid-1920s, increased attention was paid to the theory and methodology of colonization and migration and generalization of the migration policies in Russia. The following was suggested to be considered as results of colonization: 1) the degree of agricultural development of formerly unused territories; 2) the level of development of a peasants households in colonized areas; 3) the achievements of the national economy in these areas (Yamzin and Voshchinin 1926: 53). With all uncertainty of terms and indices (e.g. the degree of agricultural development of formerly unused territories), the task of transition to a new stage of colonization of the territories was set in the USSR.

However, in the late 1920s the migration policy of the Soviet state began to change radically. Efforts to encourage migration were manifested, on the one hand, in an attempt to include them in the First Five-Year plan (1926-1931) and, on the other hand, in an in-depth studies of the economic effects of migration with the purpose of its "appropriate management".

Planning migration meant the need to assess the effectiveness of this process for the socialist sector of the economy. One of the variants of the Five-Year plan (1928) shows the effectiveness of migration was estimated for two stages - the forthcoming Five-Year plan and the longer term. A restrained assessment of the effects of migration within the framework of the First Five-Year plan was rooted in understanding its limited impact on solving the grain problem, which worsened in the late 1920s. It should be noted that surveys on the effects of migration were not conducted at that time. The Five-Year plan cost and losses associated with migration management included the following items: costs for preparation of the land fund; transportation of migrants; their living arrangements; losses from insufficient sowing at exit areas; non-refunded loans and losses from low interest on loans. In the total amount of expenses (it was planned in the amount of 509,872.1 thousand rubles), the largest items included costs for the preparation of the land fund $(210,948.0$ thousand rubles) and providing living arrangements of migrants $(133,132.7$ thousand rubles) (Gokhberg 1929: 31).

The methodologically more complex estimates of effects of migration included production of new agricultural commodity values, reduced consumption in areas of departure, and development of outlying areas. In view of the real situation of migrants in the first years after arrival, increased income from agriculture was expected to be received only in the Second Five-Year plan. It was reflected in the pre-war studies of the development of migrants households in the areas of destination. The relatively slow development of new migrants households was expected to be compensated by the growth of earlier settled migrants households. It was also acknowledged that the crop capacity under "exclusively extensive grain farming" during the First Five-Year plan could not be high, and the level of migrants' farms marketability was relatively low (20\%). Collectivization was to cover $25 \%$ of migrants' farms (Gokhberg 1929: 34). In reality, the planned indicators of collectivization of migrants farms significantly lagged behind real values in the late 1920s and early 1930s. 
The 1928 version of the Five-Year plan is interesting with its conclusions related to obtaining potential income "from the development of the outlying areas". The concept of "development of the outlying areas" assumed various stages of change in the economy of these territories. The 1928 version of the plan was focused on getting additional commodity values in areas where migrants farms were no more than "little help". The major aim was to implement the concept of industrial colonization of the Urals, Karelo-Murmansk Krai and the North of the European part of the RSFSR, which was started in the late 1910s. Within this concept, migration had to play an important role in providing industry with labour, including timber and logging sector. It was planned that occupational structure of migrants was to correspond to the structure of local residents: among them, income from agriculture was 54.7\%, according to the 1924/25 Budget Survey of the Urals Statistical Department. The rest was made up of industry and crafts. Consequently, migrants were supposed to ensure interconnected development of industry and agriculture in the areas under consideration. Development of agriculture was seen as a necessary food-supply base of industrialization.

As a result, according to the approximate calculation, the income of the socialist sector of the economy from migration was to reach 688,537 thousand rubles, including additional values in agriculture - 100,078 thousand rubles, industrial values - 454,750 thousand rubles, reduction of consumption at areas of departure - 133,729 thousand rubles. Consequently, the net income from migration was planned in the amount of 178,683 thousand rubles, in the formation of which, as we see, employment in industry had to be essential (Gokhberg 1929: 35-37). Thus, the planned structure of income from migration for 1926-1931 primarily reflected the results of industrial colonization.

At the same time, the 1928 version of the Five-Year plan drew attention to future positive developments in the growth and structural transformation of the economy as a result of migration to the outlying areas through the growth of mining of various minerals, the creation of communication routes and their own food base, and logging. The development of the grain economy in the populated areas allowed to expand the crops of industrial cultivation in the areas of departure and, consequently, to improve the condition of the raw material market. Based on the experience of the United States and Canada, the development of new areas was seen as an impetus for industrial development in the old areas. In this context, migration was to be "one of the instruments to modernize agriculture, not a mere resettlement of excess population” (Gokhberg 1929: 37-38).

However, as noted above, in the late 1920s, the attitude of the state to the migration of individual peasant households radically changed. Formally, it was a result of negative assessment of the results of the migration management. It was clear that during very limited time after planned migration started in 1924 it was impossible to solve all the emerging problems. However, already in the summer of 1927, the Commission of the People's Commissariat of Agriculture of the RSFSR revealed significant "defects" in the organization of migration. In the areas of departure "defects" consisted in the spontaneous movement of tens of thousands of peasant households, in places of destination - in an unsatisfactory state of preparation of the colonization land fund and living arrangements for migrant households. The situation of migrants in the Far East was especially difficult: the norms of land ownership, which should predetermine the size of the colonization fund, have not been preliminarily established (Bolshakov 1928: 2-3, 5-6).

Critical conclusions of the Commission of the People's Commissariat of Agriculture of the RSFSR on the condition of migration management were predictable. The results of mi- 
gration in the 1920s differed significantly from pre-revolutionary ones: the scale of migration and the cost of resettlement had reduced. In the first years of Soviet power, the Migration Directorate was abolished. In the 1920s, the migration administration was newly created, however, part of its workers prejudiced the pre-revolutionary experience. The above mentioned "defects" concerned the fundamental issues of the organization of migration. Their elimination required considerable time and money. It was also believed that the role of migration objectively could increase in connection with the industrialization of the Siberian region, development of the Primorye region and the need to expand the commodity grain production (Zhdanov 1928: 65).

Given the "urgency of economic policy issues" related to the resettlement of population to the east of the Urals, in the late 1920s an attempt to revise migration management "for its reasonability" was made. The key idea was to increase the productivity of migrant households by analyzing the efficiency of capital and labour costs for resettlement. For this purpose the pre-revolutionary experience was studied; in fact it was much more effective and extensive than the Soviet migration management experience in the 1920s (Zhdanov 1929: 31 ). It should be noted that in the Soviet years annual information on article-by-article expenditures of the state on migration was not published. Materials of the survey of migrant househilds conducted in 1928 by the Research Institute of Land Management and Resettlement (NII Zemleustroystva i Pereseleniya), remained unpublished in the conditions of acute criticism of the works of the Institute in the late 1920s and its subsequent liquidation. Their fate is currently unknown.

Analysis of the efficiency of capital and labour costs for migration and settlement of migrant households and the results of their economic activity in areas of destination, required development of the appropriate methodological basis. In contrast to the needs of migrant households, which were relatively easy to solve (taking the pre-revolutionary experience into account), the task to coordinate effects of migration with the general economic (public) interests was more complicated. It called for an increase in the number elements to be evaluated, analyzed, and compared. Theoretically, the elements affecting migration included the costs of the Trans-Siberian Railway and the irrigation measures in Central Asia. No less important was the influence of other elements - the costs for resettlement, the composition of migrants, the geographical and economic conditions of the destination area, the organization of migration management, etc. The task of assessing the effects of migration was even more difficult. Indicators of migration results could include the number of settled migrant households and their productivity, as well as the complex of economic processes associated with the colonization of the new territory and meaning the impact of migration on development of agriculture, industries, transport, etc.

Here, it is necessary to emphasize the complexity of the analysis while the methodology was forcedly simplified: it admitted conditional character of a number of estimates and accepted very limited range of phenomena studied. For example, out of a large number of factors influencing migration, only the expenditures directly used to arrange it were analyzed. The effect of such expenditures was associated with productivity of migrant households, depending on the territory of destination. The statistical basis of the research was data on six provinces located in Siberia and Northern Kazakhstan, namely Tomsk, Tobolsk, Yenisei, Irkutsk, Semipalatinsk and Akmola, for the decade between 1906 and 1915. Although the principle of selection was not specifically explained, in fact the most important territories from the colonization standpoint were chosen as destination areas for migrants (Zhdanov 1928: 66, 68-69). 
Without going into a detailed description of further analysis of the efficiency of capital expenditures for resettlement, we will refer to its results, bearing in mind that the productivity of different types of households was seen as an indicator of the efficiency of migration, and the amendments to the data on agricultural output related to the III and IV settlement zones (Zhdanov 1928: 77) (Table 1).

Table 1. Relative productivity of land, labour and capital in migrant households in various zones of Western Siberia and Northern Kazakhstan in 1906-1915 (\% of households in the West Siberian forest-steppe)

\begin{tabular}{lccc}
\hline \multirow{2}{*}{ Settlement zones } & \multicolumn{3}{c}{ Gross product } \\
\cline { 2 - 4 } & $\begin{array}{c}\text { per unit } \\
\text { of agricultural area }\end{array}$ & per unit of labour & $\begin{array}{c}\text { per unit of fixed } \\
\text { capital }\end{array}$ \\
\hline I. West Siberian forest-steppe & 100 & 100 & 100 \\
\hline II. Steppe & 106 & 71 & 54 \\
\hline III. East Siberian forest-steppe & 99 & 53 & 55 \\
\hline IV. Urman and taiga & 71 & 25 & 50 \\
\hline
\end{tabular}

Source: (Zhdanov 1928: 76).

According to Table 1, the productivity of land, labour and capital met "resistance from the physical and geographical conditions of the settlement area". Most problematic, in terms of economic efficiency, were farms located in the zones of the East Siberian forest-steppe, Urman and taiga. The differences in economic efficiency between settlement areas can be seen more clearly from Table 2 .

Table 2. Level of development of migrant households in various settlement zones in 1906-1915

\begin{tabular}{|c|c|c|c|c|c|c|c|c|}
\hline \multirow[t]{2}{*}{ Settlement zones } & \multicolumn{2}{|c|}{ Fixed assets } & \multicolumn{2}{|c|}{$\begin{array}{l}\text { Gross income } \\
\text { from agriculture }\end{array}$} & \multicolumn{2}{|c|}{$\begin{array}{c}\text { Conditional net } \\
\text { income from } \\
\text { agriculture }\end{array}$} & \multicolumn{2}{|c|}{$\begin{array}{l}\text { Land purchase } \\
\text { costs }^{1}\end{array}$} \\
\hline & rubles & $\%$ & rubles & $\%$ & rubles & $\%$ & rubles & $\%$ \\
\hline $\begin{array}{l}\text { I. West Siberian } \\
\text { forest-steppe }\end{array}$ & 841 & 100 & 652.4 & 100 & 325.0 & 100 & 139 & 100 \\
\hline II. Steppe & 666 & 79.2 & 508.6 & 78.0 & 235.4 & 72.4 & 99 & 71.2 \\
\hline $\begin{array}{l}\text { III. East Siberian } \\
\text { forest-steppe }\end{array}$ & 623 & 74.1 & 485.2 & 74.4 & 219.3 & 67.5 & 57 & 41.0 \\
\hline $\begin{array}{l}\text { IV. Urman and } \\
\text { taiga }\end{array}$ & 388 & 46.1 & 261.6 & 40 & 110.0 & 33.8 & - & - \\
\hline
\end{tabular}

Source: (Zhdanov 1928: 79).

According to B.N. Zhdanov, the welfare of migrants on average reached a level typical for the average economy of European Russia in only the last pre-war five years. Migrant house-

1 In places of destination, migrant peasants have got plots of land for agricultural cultivation. Legally, these plots were the State property. Later on, migrants could purchase these plots for private property. 
holds surveyed after 1910 (according to the value of products and capital), were almost equal to the peasant farms of the Chernozem zone of European Russia. At the same time, the Urman-taiga zone lagged behind the peasant farms of the Chernozem zone of European Russia in these years. Only migrant farms with a duration of settlement from 3 to 18 years located in the West Siberian forest-steppe and steppe achieved commodity type, while the farms of the Urman-taiga zone imported grain and were poorly equipped with capital goods. It was believed that such conclusions should be an important reference point for the organization of migration at the turn of the 1920-1930s.

At the end of the 1920s, the issue of the scale and sources of financing of migration was of crucial importance. In general, the resettlement of peasants in pre-revolutionary time is estimated as a "costly" process for the state. On average, expenditures of the state per a migrant household increased from 75.6 rubles in 1885 - 1889 to 1,216.2 rubles in 1910-1914. Particular attention was also drawn to the dynamics of the funds of migrants themselves. Their role in the pre-war years had grown, thanks to the improvement of the migration management, the creation of more favourable conditions for the liquidation of farms in places of departure, reduction of travel costs, etc. As a result, the survey conducted in 19111912 in the Tomsk province showed an increase in the net capital of the migrant households: from 108.8 rubles in households, which moved 21 years ago, to 423.81 rubles in those which moved less than 3 years ago. In the structure of personal funds of migrants, a significant part (over 1/4) was proceeds from the sale of land (Zhdanov 1928: 80).

Reduction of the state expenses on the support of resettlements in the Soviet years, denomination of national currency, and significantly lowered funds of migrants brought to the conclusion that financing and organization of resettlement in the 1920s were much worse than before the First World War. The level of organization of migration and economic situation of migrants "did not give reason to think that the efficiency of resettlement expenditures would be higher than before the war" (Zhdanov 1928: 81-82). Such careful assessments could not conceal the dramatic situation of migrants in the late 1920s. In the conditions of reduced financing, as well as the influence of other factors, including ethnical, Kazakhstan's capacity to increase grain harvest was doubtful. Since migration to the Steppe region was recognized as one of the most effective, it was proposed to solve the problem of development of the grain economy with the focus on the organization of migrant farms in the Steppe zone and the use of the remnants of the colonization fund in the forest-steppe zone (Zhdanov 1928: 81-83). These findings were presented as practical results of an analysis of the efficiency of resettlement costs. However, from the academic point of view this analysis was of limited value because it did not go beyond the dependence of labour and capital efficiency on the area of settlement.

A broader view of examining the cost-effectiveness of migration meant taking into account the characteristics of migration as a social phenomenon. The principal conclusion was that the low cost of capital and labour on migration does not mean "cancellation" of migration, since it is first necessary to "eliminate" the causes of migration. At the same time, the objective nature of migration did not "cancel" search for optimal forms of organization and management of this process, i.e. the choice of the territory of settlement, the size and structure of investments, the development of a system of migrant-support instruments, etc.

Complex differentiation of factors influencing the efficiency of capital and labour, called for the development of a special methodology, especially in the calculation of national-wide economic and social efficiency of the expenditures on migration. The directions proposed for solving such a complex problem have not lost their relevance nowadays (if adopted to 
different types of migration, including international). These include the impact of capital and output growth in areas of settlement as a direct result of migration, the labour intensity of capital spent, comparison of welfare of households in areas of departure and destination, the impact of migration on the economy of destination and departure areas, etc. (Zhdanov 1929: 32-34, 40).

Therefore, the proposed approach to assessment of migration as a social phenomenon was fundamentally different from the simplistic attitude to this process that was approved in the late 1920s. Regretfully, studies on the efficiency of capital and labour remained unnoticed by contemporaries and therefore didn't receive support and development. However, for the contemporary reader, these studies are a good reminder of the difficult path of development of science and its dependence on many circumstances.

\section{Reference list}

Berkenheim AM (1902) Pereselencheskoe delo v Sibiri (po lichnym nabljudenijam i oficial'nym dannym). [Migrations to Siberia (on personal observations and official data)]. Moscow, 62 pp. (in Russian)

Bolshakov M (1928) Dal'nevostochnoe i sibirskoe pereselenie (po materialam obsledovanija Narkomzema RSFSR) [Migration to the Far East and Siberia (based on the survey of the People's Commissariat of the RSFSR)] Vestnik zemleustrojstva i pereselenija [Bulletin of Land Management and Resettlement] 4: 3-44 (in Russian)

Chaslavskiy VI (1875) Zemledel'cheskie othozhie promysly v svjazi s pereseleniem krest'jan (s kartoju) [Agricultural seasonal industries in connection with migration of peasants (with a map)] In: Bezobrazov VP (Ed.) Sbornik gosudarstvennyh znanij [Compedium of state knowledge] Vol. II. Saint Petersburg. Pp. 181 - 211 (in Russian)

Chirkin G (1917) Kolonizacionnye zadachi na russkom Severe [Tasks of colonization of the Russian North] Voprosy kolonizacii [Colonization issues] 20: 1-14 (in Russian)

Chudnovsky SL (1884) Pereselencheskoe delo na Altae (Statistiko-jekonomicheskij ocherk) [Migration management in the Altai region (Statistical and Economic Essay)] In: Potanin GN (Ed.) Zapiski Vostochno-Sibirskogo otdela imperatorskogo Russkogo geograficheskogo obshhestva [Proceedings of the East Siberian Department of the Imperial Russian Geographical Society] 1(1) Irkutsk, 154 pp. (in Russian)

Gokhberg G (1929) Pereselenie i ego vlijanie na narodnoe hozjajstvo [Migration and its impact on the national economy] Vestnik zemleustrojstva i pereselenija [Bulletin of Land Management and Resettlement] 6: 20-38 (in Russian)

Grigoriev VN (1885) Pereselenija krest'jan Rjazanskoj gubernii. S otzyvami A.I. Chuprova i A.I. Kosheleva [Migration of peasants of the Ryazan province. With comments by A.I. Chuprov and A.I. Koshelev] Moscow, 194 pp. (in Russian)

Gurvich IA (1888) Pereselenie krest'jan v Sibir'. Issledovanie [Migration of peasants to Siberia. Research] Moscow, 149 pp. (in Russian)

Isayev AA (1891) Pereselenija v russkom narodnom hozjajstve [Migration in the Russian national economy] Saint Petersburg, 192 pp. (in Russian)

Kaufman AA (1915) Pereselenie i kolonizacija [Migration and colonization] Saint Petersburg, 439 pp. (in Russian)

Kaufman AA (1915) Pereselency na novyh mestah. Po dannym novejshego pravitel'stvennogo issledovanija [Migrants at places of destination. Based on the results to the latest government study] In: 
Kaufman AA Obshhina. Pereselenie. Statistika [Community. Migration. Statistics] Moscow Pp. 299 - 320 (in Russian)

Kaufman AA (no date, a) Pereselenie i pereselencheskij vopros v Rossii. Pereselencheskaja statistika [Migrations and the migration issue in Russia. Migration statistics] Jenciklopedicheskij slovar' Russkogo bibliograficheskogo instituta [Encyclopedic Dictionary of the Russian Bibliographic Institute] 7th edition. Vol. 31. Garant. Moscow Pp. 1-7 (in Russian)

Kaufman AA (no date, b) Pereselenie i pereselencheskij vopros v Rossii [Migrations and the migration issue in Russia] Jenciklopedicheskij slovar' Russkogo bibliograficheskogo instituta [Encyclopedic Dictionary of the Russian Bibliographic Institute] 7th edition. Vol. 31. Garant. Moscow Pp. 506-547 (in Russian)

Kuznetsov VK (no date) Jekonomicheskie rezul'taty pereselenija v Sibir' i na Dal'nij Vostok [Economic effects of migration to Siberia and Far East] Voprosy kolonizacii [Colonization issues] 2: 69-83 (in Russian)

Manuilov AA (1905) Pozemel'nyj vopros v Rossii. Malozemel'e, dopolnitel'nyj nadel i arenda [Land issue in Russia. Shortage of land, additional plots, and rent] Moscow, 196 pp. (in Russian)

Nuzhdy sel'skogo hozjajstva i mery ih udovletvorenija po otzyvam zemskih sobranij [Needs of agriculture and measures of their satisfaction in the opinion of county council assemblies] (1902) 2nd edition. 120 pp. (in Russian)

Oganovsky NP (1914) Zakonomernost' agrarnoj jevoljucii [Appropriateness of agrarian evolution] In: Obnovlenie zemledel'cheskoj Rossii i agrarnaja politika [Renewal of agricultural Russia and agrarian policy] Vol. III. Issue 1: Naselenie. Pereselencheskij vopros [Population. Migration] Saratov, 334 pp. (in Russian)

Oganovsky NP (1921) Narodnoe hozjajstvo Sibiri [Economy of Siberia] A course of lectures delivered at cooperative courses for students and workers of cooperative organizations of the city of Omsk in February-March 1920. Omsk, 120 pp. (in Russian)

Romanov NN (1880) Pereselenija krest'jan Vjatskoj gubernii [Migration of peasants of the Vyatka province] Vyatka, 336 pp. (in Russian)

Simonov M (1917) O napravlenii kolonizacionnoj dejatel'nosti v blizhajshem budushhem [On the concept of colonization activity in the near future] Voprosy kolonizacii [Colonization issues] 20: 15-22 (in Russian)

Vasilchikov AI (1881) Zemlevladenie i zemledelie v Rossii i drugih evropejskih gosudarstvah [Land tenure and agriculture in Russia and other European countries]. Vol. II. 2nd. ed. Saint Petersburg, 394 pp. (in Russian)

Voshchinin V (1921) Pereselenie [Migration] In: O zemle [About land] Sbornik statej o proshlom i budushhem zemel'no-hozjajstvennogo stroitel'stva [Collection of articles on the past and future of land and economic management] Issue 1. Pp. 126-142. Moscow (in Russian)

Vsesojuznaja perepis' naselenija 1926 goda [All-Union census of the population of 1926]. (1931). Vol. 51. Moscow (in Russian)

Yadrintsev NM (1892) Sibir' kak kolonija v geograficheskom, jetnograficheskom i istoricheskom otnoshenii [Siberia as a colony from a geographical, ethnographic and historical standpoint] 2nd edition. Saint Petersburg, 720 pp. (in Russian)

Yamzin IL and Voshchinin VP (1926) Uchenie o kolonizacii i pereselenijah [The theory of colonization and migration] Moscow - Leningrad. 328 pp. (in Russian)

Zapiska Predsedatelja Soveta Ministrov i Glavnoupravljajushhego zemleustrojstvom i zemledeliem o poezdke v Sibir' i Povolzh'e v 1910 g. [Note by the Chairman of the Council of Ministers and the General Manager of Land Management and Agriculture Department on the trip to Siberia and the Volga region in 1910] (1910) Saint Petersburg (in Russian) 
Zhdanov BN (1928) Ob jeffektivnosti i trudoemkosti zatrat na pereselenie [On efficiency and labour intensity of expenses on resettlement] Severnaja Azija [Northern Asia] 4: 65-83 (in Russian)

Zhdanov BN (1929) K voprosu ob izuchenii zatrat na pereselenie [On the issue of studying the costs of migration] Vestnik zemleustrojstva i pereselenija [Bulletin of Land Management and Resettlement] 4: 31-45 (in Russian)

Zhurnaly Komissii po voprosam pereselenija i kolonizacii. 1917. Zasedanie 7 avgusta 1917 goda [Proceedings of the Commission on Resettlement and Colonization. 1917. Meeting of August 7, 1917] Voprosy kolonizacii [Colonization issues] 20: 136-167 (in Russian)

\section{Authors information}

- Valentina M. Moiseenko, Doctor in Economics, Independent researcher. E-mail: mvm. msu@gmail.com 